\title{
A preliminary study on the role of the complement regulatory protein, cluster of differentiation 55, in mice with diabetic neuropathic pain
}

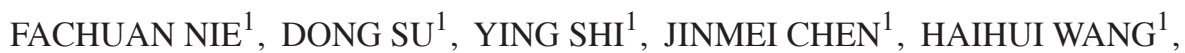 \\ WANXIANG QIN ${ }^{1}$, YAOHUA CHEN ${ }^{1}$, SUXIA WANG ${ }^{1}$ and LEI LI ${ }^{2}$ \\ ${ }^{1}$ Department of Pain, The First Affiliated Hospital, Third Military Medical University, Chongqing 400038; \\ ${ }^{2}$ Department of Anesthesiology, Women's and Children's Central Hospital, Chengdu, Sichuan 610031, P.R. China
}

Received December 22, 2013; Accepted October 3, 2014

DOI: $10.3892 / \mathrm{mmr} .2014 .2896$

\begin{abstract}
The aim of this study was to investigate the role of the complement regulatory protein cluster of differentiation 55 (CD55) in the pathogenesis of diabetic neuropathic pain (DNP). Healthy adult male C57BL/6J mice were intraperitoneally injected with streptozotocin (STZ) in order to induce DNP. Peripheral blood glucose and protein, and the mRNA expression levels of C3 and CD55 in the spinal cord were determined. In addition, the behaviors of these mice were observed. The results showed that STZ-treated mice displayed the clinical manifestations of diabetes mellitus, and that their peripheral blood glucose was markedly increased. On the 21st and 28th days following the STZ injection, the mechanical pain threshold and thermal pain threshold of the mice were dramatically reduced $(\mathrm{P}<0.05)$. IAdditionally, 14 days post-STZ injection, the mRNA expression of C3 in the spinal cord was significantly increased, which continued for 28 days. On the 21st and 28th days, the number of $\mathrm{C} 3$ positive cells in the spinal cord was markedly increased. Seven days after the STZ injection, the number of cells positive for CD55 was markedly reduced in the spinal dorsal horn and subsequently remained at a low level. The mRNA expression of CD55 also was significantly reduced $(\mathrm{P}<0.05)$ and remained so for 28 days. The reduction in the expression levels of CD55 occurred earlier than the changes in the expression of $\mathrm{C} 3$, suggesting that the downregulation of CD55 expression precedes, and has an important role regarding, the activation of $\mathrm{C} 3$ in the occurrence and development of DNP.
\end{abstract}

Correspondence to: Dr Lei Li, Department of Anesthesiology, Women's and Children's Central Hospital, 32 Shiye Road, Chengdu, Sichuan 610000, P.R. China

E-mail: fachuan_nie@sina.com

Key words: streptozotocin, diabetic neuropathic pain, complement $\mathrm{C} 3$, cluster of differentiation 55 , hyperalgesia

\section{Introduction}

Diabetic peripheral neuropathy is usually characterized by spontaneous pain, hyperalgesia and allodynia, typical features of neuropathic pain (NPP) which are an important problem, influencing the quality of life and lifespan of patients. Currently, the therapeutic efficacy of treatments for diabetic neuropathic pain (DNP) is still poor. Thus, it is imperative to investigate the pathogenesis of DNP and develop novel strategies for its treatment $(1,2)$.

Previous studies have shown that an abnormal activation of complements in the spinal dorsal horn has an important role in the occurrence and development of NPP secondary to peripheral nerve compression $(3,4)$. In type II diabetic patients with NPP, a biopsy and an immunohistochemical examination of the sural nerve revealed immunoglobulin $\mathrm{G}$ ( $\mathrm{IgG}), \mathrm{IgM}, \mathrm{C} 3$ and $\mathrm{C} 4$ stored in the perineurium and endoneurium. The expression levels of immunocompetent complements in the microvascular wall of the endoneurium were significantly higher than those in type II diabetic patients without NPP $(5,6)$.

Generally, complement regulatory proteins (CRPs) function to inactivate complements and stop cascades, thus, the functional status of the CRP determines the intensity of the complement cascade. Of the CRPs, decay-accelerating factor (DAF), or cluster of differentiation 55 (CD55), is widely expressed and has evident functions. CD55 can compete with $\mathrm{C} 2$ to bind to $\mathrm{C} 4 \mathrm{~b}$, which inhibits the assembly of the $\mathrm{C} 3 / \mathrm{C} 5$ convertase and the formation of membrane attack complex (MAC), promoting the decay of C3/C5 convertase and blocking the activation of the classical and alternative complement pathways $(7,8)$.

On the basis of above-mentioned findings, we speculated that the downregulation of the expression and activity of CD55 are crucial for the occurrence and development of DNP, and that it may be an initiator for the abnormal activation of CRPs. To confirm this hypothesis, quantitative polymerase chain reaction (qPCR) and an immunohistochemical examination were performed in order to detect the mRNA and protein expression levels of C3 and CD55 in the spinal cords of mice with DNP. In addition, the behaviors of these mice 
were observed. This study aimed to investigate the correlation between CD55 expression and the pathogenesis of DNP.

\section{Materials and methods}

Preparation of the animals. Healthy adult male C57BL/6J mice (specific pathogen free; $n=120$ ) weighing $18-20 \mathrm{~g}$ were employed in this study, provided by the Animal Experiment Center of the Third Military Medical University, Chongqing, China [Animal Medical Certificate no. SCXK (Military) 2002008]. The mice were housed ( $n=5$ per cage) in the Experimental Animal Center of Southwest Hospital (Chongqing, China). The cage floor was covered with sawdust and maintained at a temperature of $20 \pm 2{ }^{\circ} \mathrm{C}$. The animals were exposed to a strict alternating light-dark illumination pattern, each for $12 \mathrm{~h}$, and were supplied with adequate water and food. The animals were treated according to the Guide for the Care and Use of Laboratory Animals drawn up by the World Society for the Protection of Animals, and the number of animals used, as well as pain, was minimized in this study. The study was approved by the Laboratory Animal Welfare and Ethics Committee of the Third Military Medical University, PLA, (Chingqing, China). The committee conducts the work according to Chinese legislation on the protection of animals and the National Institutes of Health Guide for the Care and Use of Laboratory animals. The committee examined and approved this research project on June 27, 2012

\section{Animal groupings and experimental procedures}

Establishment of a DNP model. A total of 60 mice were randomly selected for the control group, while 60 mice were selected for the experimental group. For accommodation, the experimental group mice were housed for 3 days. Their baseline body weight, peripheral blood glucose, mechanical pain threshold and thermal pain threshold were determined. The animals fasted for $16 \mathrm{~h}$. Following sterilization of the abdomen, the mice were intraperitoneally injected with $120 \mathrm{mg} / \mathrm{kg}$ streptozotocin (STZ; Sigma-Aldrich, St. Louis, MO, USA) in a $1 \%$ citrate buffer ( $\mathrm{pH} 4.5$; Guoguang Biochemistry Co., Ltd., Zhejiang, China). In the control group, the mice were intraperitoneally treated with a citrate buffer of an equal volume $(9,10)$.

Detection. Prior to STZ injection, and at 3, 7, 14 and 21 days following, the peripheral blood glucose level was measured, and the mechanical pain threshold and thermal pain threshold were measured and compared between the two groups.

Detection of the C3 and CD55 protein and mRNA expression levels in the spinal cord. Three mice from each group were sacrificed at each time point 3, 7, 14, 21 and 28 days following the STZ injection, and an immunohistochemical examination was performed in order to detect the $\mathrm{C} 3$ and C55 expression levels in the spinal dorsal horn. A further six mice from each group were sacrificed at each time point, and the mRNA expression of C3 and C5 in the spinal cord was detected by qPCR.

\section{Observation of behavioral changes}

General behavioral observation. Following the STZ injection, the hair, water intake, urine, spontaneous activity and body weight of the mice were monitored.

Detection of the mechanical pain threshold. The mice were placed in a transparent plexiglass chamber with an audio amplifier, and their tails were placed out of the chamber. A marker was placed $3 \mathrm{~cm}$ away from the root of the tail. The mice were allowed to accommodate to the environment for $10 \mathrm{~min}$ prior to their tails being placed in an electronic tenderness instrument (YLS-3E; Huaibei Zhenghua Bio Equipment Co., Ltd., Anhui, China). Compression was administered at the marker site (at increments of $10 \mathrm{~g} / \mathrm{sec}$ ). If responses (screaming and struggling) to compression were observed, the compression was stopped and the pressure $(\mathrm{g})$ recorded. Detection was performed three times with an interval of $\sim 10 \mathrm{~min}$. The mean pressure was calculated as the mechanical pain threshold (11).

Detection of the thermal pain threshold. The mice were placed on a thick glass plate ( $3 \mathrm{~mm}$ in thickness) and allowed to accommodate to the environment for $10 \mathrm{~min}$. The foot of the right hindlimb was placed in a thermal radiation source (PL-200; Chengdu Taimeng Science and Technology Co., Ltd., Chengdu, China). The instrument was powered on. If foot elevation occurred, the radiation was automatically stopped. The time from radiation initiation to radiation discontinuation was recorded. Detection was done thrice with an interval of $\sim 10 \mathrm{~min}$. The mean time was calculated as the thermal pain threshold (12).

\section{Biochemical measurements}

Detection of peripheral blood glucose. The tails of the mice were sterilized, the tail tip was cut and blood was collected into a blood glucose test strip. Detection of blood glucose was done with a blood glucose meter (BGM501; Isotech Co., Ltd., Seoul, Korea). Following sterilization of the injured site, the mice were housed in cages (13).

Detection of expression of $C 3$ and CD55 proteins in the spinal dorsal horn by immunohistochemistry. i) Preparation of the spinal cord sections. The mice were intraperitoneally anesthetized with chloral hydrate (Moving Your Chemistry Forward, Co., Ltd., Shanghai, China). Following a thoracotomy, the heart was exposed. The mice were transcardially perfused with heparinized normal saline until the liver became white. Perfusion was done with $4 \%$ paraformaldehyde $(50 \mathrm{ml})$ at $4^{\circ} \mathrm{C}$. The spinal cord segment, L4-6, was separated and fixed in $4 \%$ paraformaldehyde (Zhejiang Guoguang Biochemistry Co., Ltd.) at $4^{\circ} \mathrm{C}$ for $24 \mathrm{~h}$. The tissues were embedded in paraffin and sectioned (thickness, $8 \mu \mathrm{m}$ ).

Immunohistochemistry. The sections were heated at $60^{\circ} \mathrm{C}$ for $2 \mathrm{~h}$, deparaffinized with xylene, hydrated with ethanol, and washed in phosphate-buffered saline (PBS; Guoguang Biochemistry Co., Ltd.). Antigen retrieval was performed in a citrate buffer in a microwave oven. Once the sections had cooled to room temperature, they were washed in PBS and treated with $50 \mu \mathrm{l}$ of a blocking buffer at room temperature for $10 \mathrm{~min}$, in order to block endogenous peroxidase, and washed in PBS. Following the addition of goat serum ( $50 \mu \mathrm{l}$; Haoranbio Co., Ltd., Shanghai, China), incubation was performed at room temperature for $10 \mathrm{~min}$. The sections were incubated with a primary antibody [50 $\mu 1 \mathrm{C} 3$ monoclonal rat anti-mouse antibody (sc-58926), dilution, 1:200; $50 \mu \mathrm{l}$ CD55 monoclonal goat anti-mouse antibody (sc-31208), dilution, 1:150; Santa Cruz 
Biotechnology, Inc., Dallas, TX, USA] at $4^{\circ} \mathrm{C}$ overnight in a humidified chamber.

Visualization. The sections were washed in PBS and treated with biotin-conjugated goat anti-rat secondary antibody (50 $\mu 1$; Santa Cruz Biotechnology, Inc.) at room temperature for 10 min. The sections were washed in PBS and incubated with horseradish peroxidase-conjugated streptavidin-biotin $(50 \mu \mathrm{l})$ at room temperature for $10 \mathrm{~min}$. Following washing in PBS, the sections were treated with diaminobenzidine for visualization (100 $\mu 1 /$ section). The sections were washed in water and counterstaining was performed with hematoxylin for $40-60 \mathrm{sec}$. These sections were treated with hydrochloric acid in ethanol, dehydrated in ethanol, transparentized in xylene and air-dried and mounted with neutral gum (Zhejiang Guoguang Biochemistry Co., Ltd.). Observation was performed under a light microscope (Phoenix Optical Group Co., Ltd., Jiangxi, China) $(14,15)$.

Detection of the mRNA expression of C3 and CD55 in the spinal cord by $q P C R$. i) Extraction of total RNA. The mice were weighed and intraperitoneally anesthetized with $5 \%$ chloral hydrate. The L4-6 spinal cord was exposed and stored in liquid nitrogen at $-80^{\circ} \mathrm{C}$. For detection, $20-40 \mathrm{mg}$ of the spinal cord was ground in liquid nitrogen and mixed with $0.7 \mathrm{ml}$ TRIzol (Beijing Kangwei Biotech Co., Ltd., Beijing, China) in the presence of chloroform for lysis. Following centrifugation at a low temperature, the supernatant was collected and mixed with isopropanol of an equal volume, followed by further centrifugation at $15,984 \mathrm{x} \mathrm{g}$ and $4^{\circ} \mathrm{C}$. The supernatant was removed and mixed with $0.7 \mathrm{ml}$ of $75 \%$ ethanol, centrifuged at a low temperature, the supernatant was removed and the pellets were maintained at room temperature for 2-3 min and dissolved in $30 \mu \mathrm{l}$ of distilled water. The resulting RNA solution was stored at $-80^{\circ} \mathrm{C}$.

Detection of the RNA concentration using an ultraviolet spectrophotometer. In brief, $1 \mu \mathrm{l}$ of RNA was dissolved in enzyme-free water $(100 \mu \mathrm{l})$ and transferred into a cuvette; $100 \mu 1$ of the enzyme-free water served as a control. The optical density (OD) was measured at $260 \mathrm{~nm}$ with an ultraviolet visible spectrophotometer (Ultrospec 4300 pro; Hitachi, Ltd., Tokyo, Japan). The RNA concentration $(\mu \mathrm{g} / \mu \mathrm{l})$ was calculated as follows: RNA concentration $=\mathrm{OD}_{260} \mathrm{x}$ folds of dilution x 40/1,000.

$q P C R$. The reaction mixture contained $2.5 \mathrm{mM}$ dNTP mix $(4 \mu \mathrm{l})$, primer mix $(2 \mu \mathrm{l})$, a RNA template $(2 \mu \mathrm{g}), 5 \mathrm{X}$ RT buffer $(4 \mu \mathrm{l}), 0.1 \mathrm{M}$ DTT $(2 \mu \mathrm{l}), 200 \mathrm{U} / \mu \mathrm{l} \mathrm{HiFi-MMLV}(1 \mu \mathrm{l})$ and RNase-free water (final, $20 \mu \mathrm{l}$ ). Following centrifugation, PCR was performed in a thermal cycler at $42^{\circ} \mathrm{C}$ for $50 \mathrm{~min}$ and then at $70^{\circ} \mathrm{C}$ for $15 \mathrm{~min}$. Following transient centrifugation, the products were stored at $-20^{\circ} \mathrm{C}$ for later use. PCR amplification was performed in the following manner: the mRNA sequence of mouse $\mathrm{C} 3$ was obtained from GenBank, and Prime premier was employed to design primers, which were synthesized by Shanghai Shengbo Biotech Co., Ltd., Shanghai, China. The primers used for C3 amplification were as follows: forward, 5'-AGCAGGTCA TCAAGTCAGGC-3' (167 bp) and reverse, 5'-GATGTAGCT GGTGTTGGGCT-3' for C3; forward, 5'-GAGTCCTTCAAC ACCCCAGC-3' (263 bp) and reverse, 5'-ATGTCACGCACG ATTTCCC-3' for $\beta$-actin. PCR of C3 was performed in a Sprint Thermal Cycler (Thermo Electron Corporation,
Milford, MA, USA). The reaction conditions were as follows: Preconditioning at $94^{\circ} \mathrm{C}$ for $2 \mathrm{~min}$, followed by a total of 35 cycles of denaturation at $94^{\circ} \mathrm{C}$ for $30 \mathrm{sec}$, annealing at $53.4^{\circ} \mathrm{C}(\mathrm{C} 3)$ or $58^{\circ} \mathrm{C}$ ( $\beta$-actin) for $30 \mathrm{sec}$, extension at $72^{\circ} \mathrm{C}$ for $30 \mathrm{sec}$ and a final extension at $73^{\circ} \mathrm{C}$ for $2 \mathrm{~min}$. The primers used for CD55 amplification were as follows: forward, 5'-CTCTGTTGCTGCTGTCCC-3' (477 bp) and reverse, 5'-CGAATA ATATGCCGGTTG-3' for CD55; forward, 5'-GAGTCCTTCAACACCCCAGC-3' (263 bp) and reverse, 5'-ATGTCACGCACGATTTCCC-3' for $\beta$-actin. The reaction conditions were as follows: predenaturation at $94^{\circ} \mathrm{C}$ for $2 \mathrm{~min}$, followed by a total of 35 cycles of denaturation at $94^{\circ} \mathrm{C}$ for $30 \mathrm{sec}$, annealing at $52^{\circ} \mathrm{C}(\mathrm{CD} 55)$ or $58^{\circ} \mathrm{C}(\beta$-actin) for $30 \mathrm{sec}$, extension at $72^{\circ} \mathrm{C}$ for $30 \mathrm{sec}$ and a final extension at $73^{\circ} \mathrm{C}$ for $2 \mathrm{~min}$.

Identification of the PCR products by agarose gel electrophoresis. A $1.2 \%$ agarose gel was melted by heating to $60^{\circ} \mathrm{C}$. Then, $10 \mu 1$ of ethidium bromide was added. The liquid agarose was added to a tray and cooled to room temperature. The gel was placed in an electrophoresis chamber, and 0.5X TBE was added until the gel was immersed in the solution. The samples were added to the gel $(5 \mu \mathrm{l})$, and a DNA marker $(5 \mu \mathrm{l})$ was added to the left well. Electrophoresis was performed at $100 \mathrm{~V}$ until a blue band reached two-thirds of way to the lower edge. Images were captured and analyzed with a Gel Doc 2000 gel image analysis $(16,17)$.

Statistical analysis. Statistical analysis was performed with SPSS 13.0 software (SPSS., Inc., Chicago, IL, USA). The data are expressed as the mean \pm standard deviation (SD). The measurement data and numeration data were statistically analyzed with a $t$-test and $\chi^{2}$ test, respectively. $\mathrm{P}<0.05$ was considered to indicate a statistically significant difference.

\section{Results}

Behavioral changes. In the control group, the mice had smooth, soft hair, their water intake and urine volume remained unchanged and their blood glucose was stable. In the experimental group, the mice had matted hair, their water intake and urine volume increased significantly, their level of spontaneous activity was reduced, and their body weight was decreased. Their peripheral blood glucose was markedly increased 3, 7, 14 and 21 days following the STZ injection. In the control group, the mechanical pain threshold and thermal pain threshold remained unchanged. In the experimental group, the mechanical pain threshold and thermal pain threshold began to decrease 14 days following the STZ injection. The mechanical pain threshold and thermal pain threshold were dramatically decreased 21 and 28 days following the STZ injection (Table I).

Immunohistochemistry of the spinal dorsal horn. The number of $\mathrm{C} 3$ positive cells began to increase in the spinal dorsal horn 3 , 7 and 14 days following an intraperitoneal injection of STZ. The number of $\mathrm{C} 3$ positive cells including astrocytes and microglia markedly increased 21 and 28 days after the STZ injection (Figs. 1 and 2).

Agarose gel electrophoresis of the qPCR products. A band was noted at $263 \mathrm{bp}$ (Fig. 3) that was consistent with the length of $\mathrm{C} 3$. 
Table I. Blood glucose levels and pain thresholds of the mice at different time points.

\begin{tabular}{|c|c|c|c|c|c|c|c|}
\hline \multirow[b]{2}{*}{ Item } & \multirow[b]{2}{*}{ Group } & \multirow{2}{*}{$\begin{array}{l}\text { Before STZ } \\
\text { injection (n) }\end{array}$} & \multicolumn{5}{|c|}{ After STZ injection } \\
\hline & & & 3 days $(n)$ & 7 days (n) & 14 days (n) & 21 days $(\mathrm{n})$ & 28 days (n) \\
\hline \multirow{2}{*}{$\begin{array}{l}\text { Blood } \\
\text { glucose } \\
(\mathrm{mmol} / \mathrm{l})\end{array}$} & Control & $5.02 \pm 0.39(10)$ & $5.38 \pm 0.82(10)$ & $5.66 \pm 0.88(10)$ & $5.13 \pm 0.92(10)$ & $5.37 \pm 0.92(10)$ & $5.02 \pm 0.39(10)$ \\
\hline & STZ & $5.03 \pm 0.80(10)$ & $24.9 \pm 3.77^{\mathrm{a,c}}(10)$ & $24.9 \pm 3.92^{\mathrm{a}, \mathrm{c}}(10)$ & $25.6 \pm 2.82^{a, c}(10)$ & $25.2 \pm 4.82^{\mathrm{a}, \mathrm{c}}(10)$ & $24.3 \pm 3.25^{\mathrm{a}, \mathrm{c}}(10)$ \\
\hline \multirow[t]{2}{*}{ MPT (g) } & Control & $219 \pm 20.7(40)$ & $210 \pm 24.7(40)$ & $227 \pm 29.3(40)$ & $220 \pm 24.0(40)$ & $219 \pm 28.8(40)$ & $207 \pm 26.1(40)$ \\
\hline & STZ & $216 \pm 14.2(40)$ & $199 \pm 22.0(40)$ & $189 \pm 30.8^{\mathrm{b}}(40)$ & $199 \pm 27.5(40)$ & $126 \pm 28.6^{\mathrm{a}, \mathrm{c}}(40)$ & $128 \pm 34.7^{\mathrm{a}, \mathrm{c}}(40)$ \\
\hline \multirow[t]{2}{*}{ TPT (s) } & Control & $9.9 \pm 0.43(40)$ & $9.4 \pm 0.83(40)$ & $9.8 \pm 0.53(40)$ & $9.7 \pm 0.87(40)$ & $9.7 \pm 0.95(40)$ & $9.7 \pm 0.89(40)$ \\
\hline & STZ & $9.7 \pm 0.41(40)$ & $9.4 \pm 0.89(40)$ & $9.3 \pm 0.73(40)$ & $8.9 \pm 1.68(40)$ & $6.2 \pm 1.61^{\mathrm{a}, \mathrm{c}}(40)$ & $5.7 \pm 2.14^{\mathrm{a}, \mathrm{c}}(40)$ \\
\hline
\end{tabular}

${ }^{a} \mathrm{P}<0.01$ vs. prior to an STZ injection (Student's t-test). ${ }^{\mathrm{b}} \mathrm{P}<0.05$ and ${ }^{\mathrm{c}} \mathrm{P}<0.01$ vs. the control group at corresponding time points by using a Student's t-test. Data are presented as the mean \pm standard deviation. MPT, mechanical pain threshold; STZ, streptozotocin; TPT, thermal pain threshold.

Table II. mRNA expression of C3 in the spinal cord of mice.

\begin{tabular}{|c|c|c|c|c|c|c|}
\hline \multirow[b]{2}{*}{ Group } & \multirow[b]{2}{*}{ Before STZ } & \multicolumn{5}{|c|}{ Days post-STZ injection } \\
\hline & & 3 & 7 & 14 & 21 & 28 \\
\hline Control & $0.17 \pm 0.021$ & $0.16 \pm 0.013$ & $0.19 \pm 0.017$ & $0.17 \pm 0.023$ & $0.16 \pm 0.018$ & $0.17 \pm 0.024$ \\
\hline STZ & $0.15 \pm 0.015$ & $0.18 \pm 0.018$ & $0.20 \pm 0.011$ & $0.45 \pm 0.089^{\mathrm{a}, \mathrm{b}}$ & $0.53 \pm 0.094^{\mathrm{a}, \mathrm{b}}$ & $0.70 \pm 0.088^{\mathrm{a}, \mathrm{b}}$ \\
\hline
\end{tabular}

${ }^{\mathrm{a}} \mathrm{P}<0.01$ vs. prior to an STZ injection (Student's t-test). ${ }^{\mathrm{b}} \mathrm{P}<0.01 \mathrm{vs}$. the control group at corresponding time points (Student's t-test). Data are presented as the mean \pm standard deviation; $n=6$. STZ, streptozotocin.

Table III. Cluster of differentiation 55 mRNA expression in the spinal cord of mice at different time points.

\begin{tabular}{|c|c|c|c|c|c|c|}
\hline \multirow[b]{2}{*}{ Group } & \multirow[b]{2}{*}{ Before STZ injection } & \multicolumn{5}{|c|}{ Days post-STZ injection } \\
\hline & & 3 & 7 & 14 & 21 & 28 \\
\hline Control & $0.89 \pm 0.24$ & $0.79 \pm 0.21$ & $0.78 \pm 0.17$ & $0.82 \pm 0.27$ & $0.80 \pm 0.19$ & $0.85 \pm 0.18$ \\
\hline STZ & $0.85 \pm 0.13$ & $0.78 \pm 0.18$ & $0.61 \pm 0.14^{\mathrm{a}}$ & $0.54 \pm 0.21^{\mathrm{b}, \mathrm{c}}$ & $0.41 \pm 0.12^{\mathrm{b}, \mathrm{c}}$ & $0.23 \pm 0.12^{\mathrm{b}, \mathrm{c}}$ \\
\hline
\end{tabular}

${ }^{\mathrm{a}} \mathrm{P}<0.05$ and ${ }^{\mathrm{b}} \mathrm{P}<0.01 \mathrm{vs}$. before an $\mathrm{STZ}$ injection (Student's t-test). ${ }^{\mathrm{c}} \mathrm{P}<0.01 \mathrm{vs}$. the control group at corresponding time points (Student's t-test). Data are presented as the mean \pm standard deviation; $n=6$. STZ, streptozotocin.

Quantity One analysis software version 4.0 (Bio-Rad, Hercules, CA, USA) was employed in order to detect the OD of the C3 and the $\beta$-actin bands. Fourteen days after the STZ injection, the mRNA expression increased dramatically, as compared with that prior to the STZ injection $(\mathrm{P}<0.05)$, and this increase continued until 28 days after the STZ injection (Table II).

In the experimental group, 3 days after an intraperitoneal injection of STZ, the number of CD55 positive cells in the spinal dorsal horn began to decline. Seven days after the STZ injection, the number of CD55 positive cells in the spinal dorsal horn was markedly reduced and remained at a low level (Figs. 4 and 5).

mRNA expression of CD55 in the spinal cord. Following 1.2\% agarose gel electrophoresis, a band was noted at 477 bp that was consistent with the length of CD55 (Fig. 6). Quantity One version 4.0 was employed in order to detect the OD of CD55 and $\beta$-actin (Table III). When compared with the control group, the mRNA expression of CD55 was markedly reduced 7 days post-STZ injection $(\mathrm{P}<0.05)$, and this reduction continued for 28 days following the STZ injection.

\section{Discussion}

Previous studies have shown that the occurrence and development of NPP secondary to peripheral nerve injury is closely associated with the abnormal activation of complements $(3,4)$. Neurons have fewer CRPs. When complements act on neurons, activated complements cannot be inactivated in a timely ma 


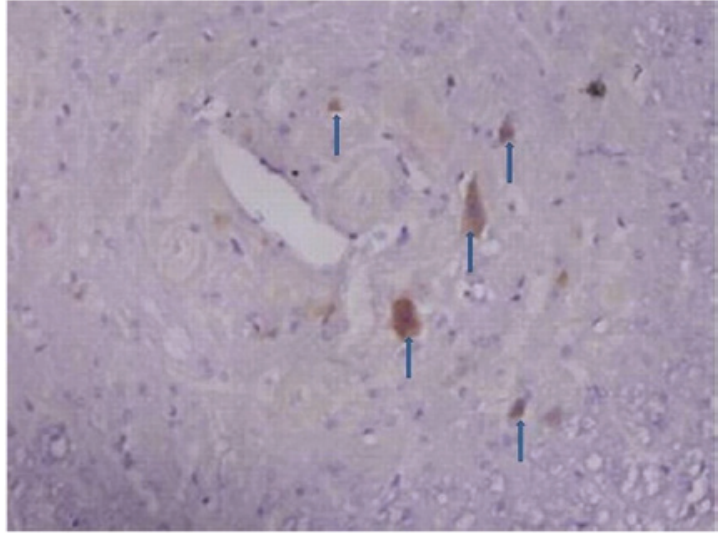

Figure 1. In the control group, the number of $\mathrm{C} 3$ positive cells in the spinal dorsal horn was small (arrows indicate brown granules in the cytoplasm), and there were 2-6 cells in each field at a high magnification (x400).

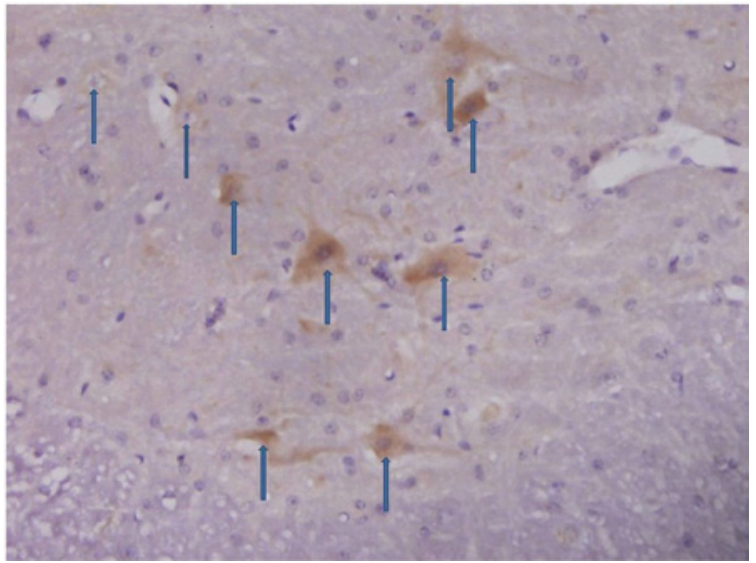

Figure 2. In the experimental group, the number of $\mathrm{C} 3$ positive cells markedly increased 21 days after a streptozotocin injection (arrows indicate brown granules in the cytoplasm), and there were 10 cells in each field at a high magnification $(\mathrm{x} 400)$.

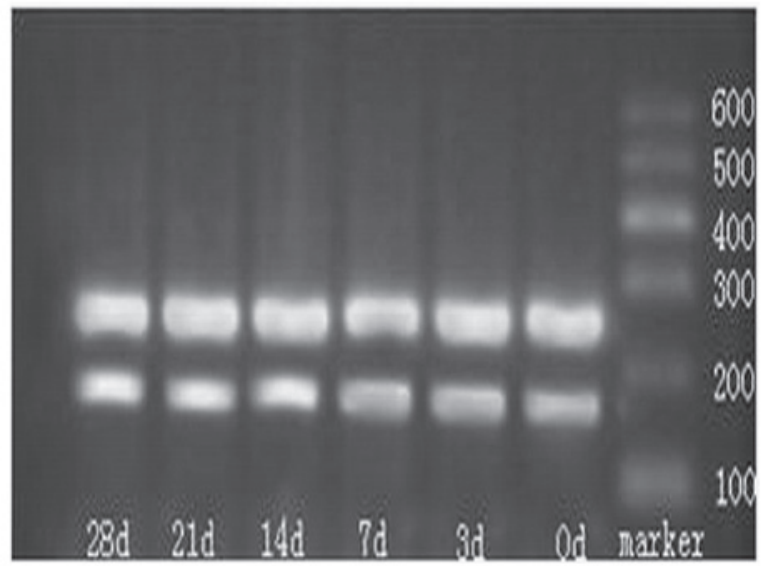

Figure 3. Detection of the mRNA expression of $\mathrm{C} 3$ in the spinal cord by quantitative polymerase chain reaction. A band was noted at 263 bp that was consistent with the length of $\mathrm{C} 3$. d, days.

and thus are unable to block the attack of neurons by MAC. The attack of neurons by MACs results in an increase in the permeability of the neural membrane, and a large amount

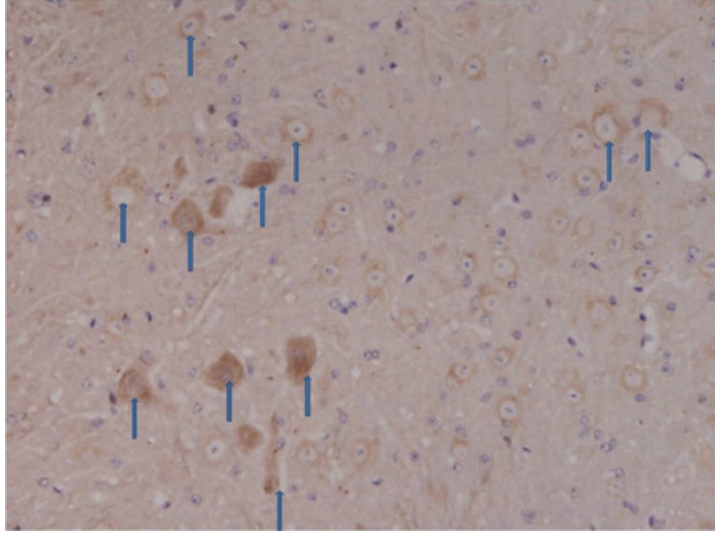

Figure 4. In the control group, the number of cluster of differentiation 55 positive cells was large (arrows indicate brown granules in the cytoplasm), and there were 8-12 cells in each field at a high magnification (x400).

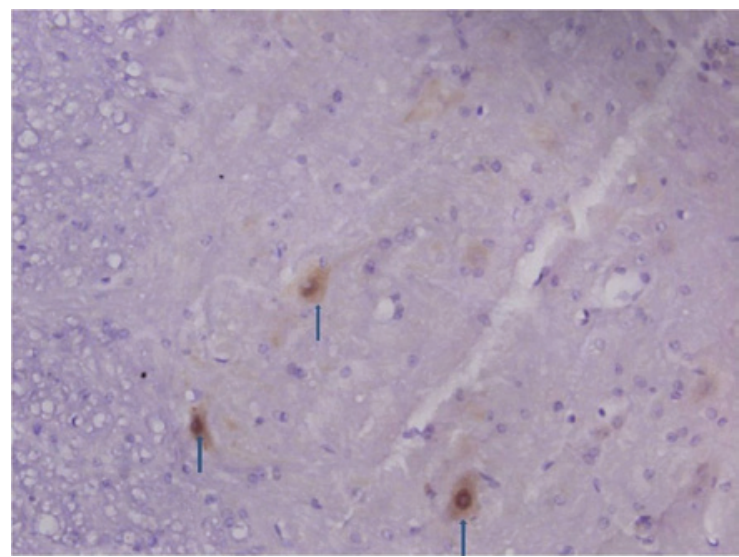

Figure 5. In the experimental group, seven days after an intraperitoneal injection of streptozotocin, the number of cluster of differentiation 55 positive cells was markedly decreased in the spinal dorsal horn of the mice (arrows indicate brown granules in the cytoplasm), and there were $\sim 5$ cells in each field at a high magnification $(\mathrm{x} 400)$.

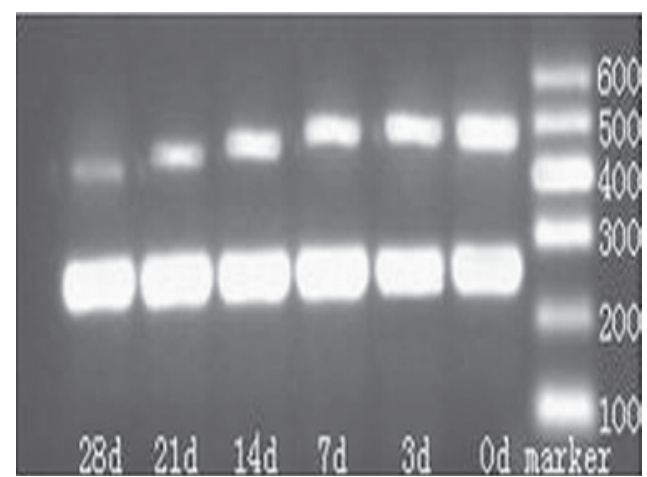

Figure 6. A quantitative polymerase chain reaction analysis of the cluster of differentiation 55 mRNA expression in the spinal cord of mice. d, days.

of $\mathrm{Ca}^{2+}$ enters the neurons. The excitability of the neurons elevates, and a large amount of reactive oxygen species are released, which in turn increase the sensitivity the of neurons to complements. This cycle finally leads to the excitotoxicity of the neurons, resulting in hyperalgesia $(18,19)$. Neurons with increased excitotoxicity may release a large amount of gluta- 
mate and ATP, which act on glial cells, leading to the release of a large amount of pro-inflammatory cytokines. This further activates more complements, resulting in a vicious cycle and subsequent immune injury to the nerves (20).

In an animal model of DNP, there were prerequisites for the activation of alternative and classic pathways. Thus, a DNP model has been used as the optimal tool for the investigation of abnormal complement activation in NPP. Whether the occurrence of DNP is associated with abnormal complement activation, as in NPP secondary to peripheral nerve injury, remains unclear.

Currently, in diabetic animal models, an intraperitoneal injection of STZ is widely used to induce diabetes. STZ is a compound with nitroso groups that causes diabetes in one of the following ways: i) It may directly damage the islet $\beta$ cells, STZ enters the islet $\beta$ cells via the glucose transporter 2 and then reduces coenzyme I (nicotinamide adenine dinucleotide) in the islet $\beta$ cells, resulting in $\beta$-cell death; ii) it may induce the production of nitric oxide (NO) and free radicals, resulting in $\beta$-cell death; or iii) STZ may induce autoimmune reactions, resulting in damage to the $\beta$ cells $(21,22)$. In the present study, a diabetes mellitus (DM) mouse model was successfully established, and the clinical manifestations of DM were clear (polyuria, polydipsia, polyphagia and emaciation). In addition, following an intraperitoneal injection of STZ, the mechanical and thermal pain thresholds were significantly reduced in the C57BL/6J mice. These findings were consistent with those reported by Courteix et al (23). The occurrence of DNP is closely associated with the course of DM. The incidence of NPP increases over the course of DM (24).

In the present study, the results showed that 14 days after an STZ injection, the mRNA expression of C3 significantly increased in the spinal cord of mice and continued to increase, which was consistent with the hyperalgesic time course in these mice. Twenty-one days after an STZ injection, the number of $\mathrm{C} 3$ positive cells had markedly increased in the spinal dorsal horn, and continued to increase until the end of the study (28 days). The results revealed that the number of mice with hyperalgesia was small 14 days following the STZ injection, and no increase in the C3 protein expression was evident. Protein production involves transcription and translation, and thus the increase in the mRNA expression of C3 was observed earlier than that of the protein expression of C3 $(25,26)$. The findings of the current study at the protein and mRNA levels confirmed that the occurrence and development of DNP is closely associated with an abnormal activation of complements in the spinal dorsal horn, as in NPP following peripheral nerve injury $(27,28)$.

Activation of the complement system is strictly controlled by CRPs. Abnormalities in the expression and function of CRP may cause an abnormal activation of the complement system, resulting in tissue damage. There is evidence that the expression of certain membrane-bound CRPs (mCRPs) is influenced by blood glucose and insulin. Of these mCRPs, CD46, CD55 and CD59 are widely expressed, have a variety of functions and are closely associated with the pathogenesis of DM (29,30). CD55 is also known as a DAF and is widely expressed in tissues. In the central nervous system, the astrocytes, microglia and neurons can synthesize and express CD55 and its receptor. CD55 primarily competes with $\mathrm{C} 2$ in order to bind to $\mathrm{C} 4 \mathrm{~b}$, inhibits the formation of $\mathrm{C} 3$ convertase and promotes the decay of $\mathrm{C} 3 / \mathrm{C} 5$ convertase, which avoids the overdeposition and activation of $\mathrm{C} 3$ and $\mathrm{C} 5$ and inhibits the activation of the classic and alternative pathways $(31,32)$. Previous studies have shown that in mice with CD55 knock out and myasthenia gravis (MG) induction, the MG symptoms were more severe, there was a large amount of $\mathrm{C} 3$ at the neuromuscular junctions and the pathological changes were more obvious compared with mice that had MG alone (33). In rats with STZ-induced diabetic retinopathy, an increase in complement activation was accompanied by a reduction in the expression of CD55 and CD59 (34). Thus, we hypothesize that the downregulated expression and activation of CD55 in the spinal cord may be one of the mechanisms that initiate abnormal complement activation and an increase in C3 in NPP.

In the present study, qPCR and an immunohistochemical examination were employed in order to detect CD55 expression in the spinal dorsal horn of mice with STZ-induced DNP at different time points. The results demonstrated that the mRNA and protein expression of CD55 in the spinal dorsal horn was significantly reduced 3 days after an STZ injection; this reduction continued for 28 days. The reduction in CD55 expression was earlier than the increase in C3 expression, which is consistent with expectations. The results demonstrated that the downregulated CD55 expression occurred prior to an abnormal $\mathrm{C} 3$ activation, and had an important role in the occurrence and development of DNP, which may be an initiator of abnormal complement activation that is involved in the occurrence and development of NPP.

\section{Acknowledgements}

The authors extend their gratitude to Professor Jiangkai Lin in the Department of Neurosurgery, Southwest Hospital, who made several suggestions for improving the technical details of the experiment. This study was supported by grants from the National Natural Science Foundation of China (NSFC-30772077).

\section{References}

1. Kessler NJ and Hong J: Whole body vibration therapy for painful diabetic peripheral neuropathy: a pilot study. J Bodyw Mov Ther 17: 518-522, 2013.

2. Kalra B, Kalra S and Bajaj S: Vulvodynia: An unrecognized diabetic neuropathic syndrome. Indian J Endocrinol Metab 17: 787-789, 2013.

3. Nie F, Wang J, Su D, Shi Y, Chen J, Wang H, Qin W and Shi L: Abnormal activation of complement $\mathrm{C} 3$ in the spinal dorsal horn is closely associated with progression of neuropathic pain. Int J Mol Med 31: 1333-1342, 2013.

4. Levin ME, Jin JG, Ji RR, Tong J, Pomonis JD, Lavery DJ, Miller SW and Chiang LW: Complement activation in the peripheral nervous system following the spinal nerve ligation model of neuropathic pain. Pain 137: 182-201, 2008.

5. Rosoklija GB, Dwork AJ, Younger DS, Karlikaya G, Latov N and Hays AP: Local activation of the complement system in endoneurial microvessels of diabetic neuropathy. Acta Neuropathol 99: 55-62, 2000.

6. Lalive PH, Truffert A, Magistris MR, Landis T and Dosso A: Peripheral autoimmune neuropathy assessed using corneal in vivo confocal microscopy. Arch Neurol 66: 403-405, 2009

7. Mamidi S, Cinci M, Hasmann M, Fehring V and Kirschfink M: Lipoplex mediated silencing of membrane regulators (CD46, CD55 and CD59) enhances complement-dependent anti-tumor activity of trastuzumab and pertuzumab. Mol Oncol 7: 580-594, 2013. 
8. Bani-Ahmad M, El-Amouri IS, Ko CM, Lin F, Tang-Feldman Y and Oakley OR: The role of decay accelerating factor in the immunopathogenesis of cytomegalovirus infection. Clin Exp Immunol 163: 199-206, 2011

9. Galeotti N, Maidecchi A, Mattoli L, Burico M and Ghelardini C: St. John's Wort seed and feverfew flower extracts relieve painful diabetic neuropathy in a rat model of diabetes. Fitoterapia 92: 23-33, 2014.

10. Ikeda H, Ikegami M, Kai M, Ohsawa M and Kamei J: Activation of spinal cannabinoid CB2 receptors inhibits neuropathic pain in streptozotocin-induced diabetic mice. Neuroscience 250: 446-454, 2013

11. Shukla M, Quirion R and Ma W: Reduced expression of pain mediators and pain sensitivity in amyloid precursor protein over-expressing CRND8 transgenic mice. Neuroscience 250: 92-101, 2013

12. Murakami T, Kanchiku T, Suzuki H, Imajo Y, Yoshida Y, Nomura H, Cui D, Ishikawa T, Ikeda E and Taguchi T: Anti-interleukin-6 receptor antibody reduces neuropathic pain following spinal cord injury in mice. Exp Ther Med 6: 1194-1198, 2013.

13. Bak EJ, Kim J, Jang S, Woo GH, Yoon HG, Yoo YJ and Cha JH: Gallic acid improves glucose tolerance and triglyceride concentration in diet-induced obesity mice. Scand J Clin Lab Invest 73 : 607-614, 2013.

14. Schmitt J, Roderfeld M, Sabrane K, Zhang P, Tian Y, Mertens JC, Frei P, Stieger B, Weber A, Müllhaupt B, Roeb E and Geier A: Complement factor C5 deficiency significantly delays the progression of biliary fibrosis in bile duct-ligated mice. Biochem Biophys Res Commun 418: 445-450, 2012.

15. Kato C, Kato A, Adachi K, Fujii E, Isobe K, Watanabe T, Ito T and Suzuki M: Expression of membrane complement regulatory proteins Crry and CD55 in normal rats. J Toxicol Pathol 26: 223-236, 2013

16. Mishra J, Sahoo PK, Mohanty BR and Das A: Sequence information, ontogeny and tissue-specific expression of complement component $\mathrm{C} 3$ in Indian major carp, Labeo rohita (Hamilton). Indian J Exp Biol 47: 672-678, 2009.

17. Zell S, Geis N, Rutz R, Schultz S, Giese T and Kirschfink M: Down-regulation of CD55 and CD46 expression by anti-sense phosphorothioate oligonucleotides (S-ODNs) sensitizes tumour cells to complement attack. Clin Exp Immunol 150: 576-584, 2007.

18. Loo LS and McNamara JO: Impaired volume regulation is the mechanism of excitotoxic sensitization to complement. J Neurosci 26: 10177-10187, 2006.

19. Tegla CA, Cudrici C, Rus V, Ito T, Vlaicu S, Singh A and Rus H: Neuroprotective effects of the complement terminal pathway during demyelination: implications for oligodendrocyte survival. J Neuroimmunol 213: 3-11, 2009.

20. Tender GC, Li YY and Cui JG: The role of nerve growth factor in neuropathic pain inhibition produced by resiniferatoxin treatment in the dorsal root ganglia. Neurosurgery 73: 158-166, 2013.
21. Sundaram B, Singhal K and Sandhir R: Ameliorating effect of chromium administration on hepatic glucose metabolism in streptozotocin-induced experimental diabetes. Biofactors 38: 59-68, 2012.

22. Pandey AK, Gupta PP and Lal VK: Preclinical evaluation of hypoglycemic activity of Ipomoea digitata tuber in streptozotocin-induced diabetic rats. J Basic Clin Physiol Pharmacol 24: 35-39, 2013.

23. Courteix C, Eschalier A and Lavarenne J: Streptozocin-induced diabetic rats: behavioural evidence for a model of chronic pain. Pain 53: 81-88, 1993.

24. Suehiro K, Funao T, Fujimoto Y, Yamada T, Mori T and Nishikawa K: Relationship between noradrenaline release in the locus coeruleus and antiallodynic efficacy of analgesics in rats with painful diabetic neuropathy. Life Sci 92: 1138-1144, 2013.

25. Hsieh CC, Chou HS, Yang HR, Lin F, Bhatt S, Qin J, Wang L, Fung JJ, Qian S and Lu L: The role of complement component 3 (C3) in differentiation of myeloid-derived suppressor cells. Blood 121: 1760-1768, 2013.

26. Berg A, Zelano J, Stephan A, Thams S, Barres BA, Pekny M, Pekna $M$ and Cullheim S: Reduced removal of synaptic terminals from axotomized spinal motoneurons in the absence of complement C3. Exp Neurol 237: 8-17, 2012.

27. Mika J, Zychowska M, Popiolek-Barczyk K, Rojewska E and Przewlocka B: Importance of glial activation in neuropathic pain. Eur J Pharmacol 716: 106-119, 2013.

28. Doehring A, Geisslinger G and Lötsch J: Epigenetics in pain and analgesia: an imminent research field. Eur J Pain 15: 11-16, 2011.

29. Yamamoto H, Fara AF, Dasgupta P and Kemper C: CD46: the 'multitasker' of complement proteins. Int J Biochem Cell Biol 45: 2808-2820, 2013.

30. Nevo Y, Ben-Zeev B, Tabib A, Straussberg R, Anikster Y, Shorer Z, Fattal-Valevski A, Ta-Shma A, Aharoni S, Rabie M, Zenvirt S, Goldshmidt H, Fellig Y, Shaag A, Mevorach D and Elpeleg O: CD59 deficiency is associated with chronic hemolysis and childhood relapsing immune-mediated polyneuropathy. Blood 121: 129-135, 2013

31. Margolles-Clark E, Jacques-Silva MC, Ganesan L, Umland O, Kenyon NS, Ricordi C, Berggren PO and Buchwald P: Suramin inhibits the CD40-CD154 costimulatory interaction: a possible mechanism for immunosuppressive effects. Biochem Pharmacol 77: 1236-1245, 2009.

32. Nowicki B and Nowicki S: DAF as a therapeutic target for steroid hormones: implications for host-pathogen interactions. Adv Exp Med Biol 735: 83-96, 2013.

33. Lin F, Kaminski HJ, Conti-Fine BM, et al: Markedly enhanced susceptibility to experimental autoimmune myasthenia gravis in the absence of decay-accelerating factor protection. J Clin Invest 110: 1269-1274, 2002.

34. Zhang J, Gerhardinger C and Lorenzi M: Early complement activation and decreased levels of glycosylphosphatidylinositol-anchored complement inhibitors in human and experimental diabetic retinopathy. Diabetes 51: 3499-3504, 2002. 